\title{
Using Jerusalem Artichoke to Extract Heavy Metals from Municipal Sewage Sludge Amended Soil
}

\author{
Jacek Antonkiewicz ${ }^{1 *}$, Barbara Kołodziej ${ }^{2}$, Elżbieta Jolanta Bielińska ${ }^{3}$, \\ Robert Witkowicz ${ }^{4}$, Sylwester Tabor ${ }^{5}$ \\ ${ }^{1}$ Department of Agricultural and Environmental Chemistry, University of Agriculture in Kraków, \\ 31-120 Kraków, Poland \\ ${ }^{2}$ Department of Industrial and Medicinal Plants, University of Life Sciences in Lublin, \\ 20-950 Lublin, Poland \\ ${ }^{3}$ Institute of Soil Science, Environment Engineering and Management, University of Life Sciences in Lublin, \\ 20-950 Lublin, Poland \\ ${ }^{4}$ Institute of Plant Production, University of Agriculture in Kraków, \\ 31-120 Kraków, Poland \\ ${ }^{5}$ Institute of Agricultural Engineering and Informatics, University of Agriculture in Kraków, \\ 30-149 Kraków, Poland
}

Received: 9 March 2017

Accepted: 21 June 2017

\begin{abstract}
The aim of our research was to assess the effectiveness of phytoextraction of heavy metals from sewage sludge by 'Rubik' and 'Albik' varieties of Jerusalem artichoke. The 6-year field experiment involved four levels of fertilization with sewage sludge at doses of $0,10,20,40$, and $60 \mathrm{Mg}$ DM sludge $\cdot \mathrm{ha}^{-1}$. The research evaluated the amount of Jerusalem artichoke yield as well as the uptake and use of heavy metals by the Jerusalem artichoke varieties.

It was established that increasing doses of sewage sludge had significantly increased the yield of the Jerusalem artichoke varieties. Increasing doses of sewage sludge also had a significant effect on the increase in the content of heavy metals in aboveground parts of plants. The highest heavy metal uptake with the yield of the Jerusalem artichoke varieties was observed at a dose of $60 \mathrm{Mg} \mathrm{DM} \cdot \mathrm{ha}^{-1}$. Among the tested varieties of Jerusalem artichoke, Albik had higher yield, higher content and uptake of heavy metals, and greater recovery of these elements as compared to Rubik. Therefore, based on the obtained research results, Albik can be recommended for phytosequestration of heavy metals from sewage sludge amended soil.
\end{abstract}

Keywords: Helianthus tuberosus, heavy metals, phytoremediation, sewage sludge, varieties

*e-mail: rrantonk@cyf-kr.edu.pl 


\section{Introduction}

Some plants have a special tolerance to high concentrations of heavy metals in tissues, without harming growth and development [1-2]. They belong to the so-called hyperaccumulators, which have been found to accumulate large amounts of heavy metals [34]. It is recommended that phytoremediation of soils contaminated with heavy metals be carried out using plant species of different applications, including grasses and energy crops [5-7].

Currently, Jerusalem artichoke (Helianthus tuberosus L.), also known as topinambur, is becoming increasingly popular among researchers of phytoremediation plants. This plant comes from North America and belongs to the Asteraceae family [8]. Jerusalem artichoke is a species that can be used in various branches of the food, pharmaceutical, chemical, and power industries [910]. Topinambour biomass is used as a raw material for production of biogas and biodiesel [11-12]. The Jerusalem artichoke, also called earth apple, is a perfect source of fructose and a raw material for ethanol production [13].

A high-yield potential, easy cultivation, low cost of setting up a plantation, and a substantial ability to adapt to climatic conditions speak in favor of adopting Jerusalem artichoke cultivation in Poland and in the world. The viable possibility of obtaining high yields is a reason for studying this plant, also with respect to phytoremediation $[8,14]$. Our previous research also showed that Jerusalem artichoke is suitable for phytoremediation of soils contaminated with heavy metals [15].

It is permitted to use municipal sewage sludge in agriculture, in reclamation of landfills and post-industrial areas, provided that environmental standards are met [16-17]. When using municipal sewage sludge and other organic waste in reclaiming post-industrial areas, we introduce not only nutrients, but also heavy metals that can constitute a substantial ecological and economic problem [18-19].

In the case of soil contamination with heavy metals by using large doses of sewage sludge, it is rational to introduce vegetation with a high phytoextraction potential $[4,20]$. Plants with a high phytoextraction potential include, among other things, Jerusalem artichoke, miscanthus, and spartina [21-22]. Using the process of phytoextraction of heavy metals from sewage sludge is an alternative method of soil cleaning $[2,5,23]$. Scientific literature indicates that there is little research on assessing the applicability of different Jerusalem artichoke varieties for phytoextraction of heavy metals from municipal sewage sludge used on landfills or in reclaiming postindustrial areas.

The aim of our research was to verify (in field conditions) the efficacy of phytoremediation of soils from heavy metals that have been introduced with doses of municipal sewage sludge. Two varieties of Jerusalem artichoke, 'Rubik' and 'Albik,' were used in the experiment. They were evaluated with respect to the amount of Jerusalem artichoke yield as well as the uptake and use of heavy metals from sewage sludge. The effect of municipal sewage sludge on biological activity of the soil on which the Jerusalem artichoke varieties were cultivated was also assessed. Based on the abovementioned parameters, a variety for phytoextraction of heavy metals from soil amended with sewage sludge was designated.

Such a way of using Jerusalem artichoke varieties in phytoextraction may bring a positive ecological and economic effect, especially in post-industrial areas and landfills. Jerusalem artichoke plants, on account of their high yield, can purify soil from heavy metals and other pollutants. They also make use of nutrients that can be found in sewage sludge. It is worth underlining that the obtained Jerusalem artichoke biomass was used only for energy purposes.

\section{Material and Methods}

Research on the effect of increasing doses of municipal sewage sludge on phytoextraction of heavy metals by Jerusalem artichoke varieties was conducted in 200813. The research was conducted in an area that belongs to the municipal sewage treatment plant in Janów Lubelski [50'43'17.7' $\mathrm{N} 22^{\circ} 22^{\prime} 08.0^{\prime \prime} \mathrm{E}$ ] in southeastern Poland. Municipal sewage sludge originated from mechanical and biological sewage treatment plants. The experiment was part of long-term research on using sewage sludge in cultivating different species of energy crops. The research was aimed at selecting species that would be the most useful for phytoremediation and at the same time have favorable energy parameters.

\section{Soil and Municipal Sewage Sludge}

The soil on which the experiment was set up was classified as clay loam (CL), (Table 1) [24-25]. According to WRB classification, the soil is included in Cambisols/ Inceptisols [26].

The soil had a slightly acidic reaction, and the content of available phosphorus and potassium was at a low level, whereas magnesium content was at a very low level. Heavy metal content in the soil did not exceed acceptable values for using municipal sewage sludge for reclamation $[16,27]$.

Municipal sewage sludge, as organic waste with catalogue number 190805 [28], had been stabilized and hygienized before use. It came from the sewage treatment plant in Janów Lubelski. The municipal sewage sludge was applied once and mixed with soil surface layer at a depth of $20 \mathrm{~cm}$ in late autumn 2007. Due to the low potassium content in the sewage sludge, supplemental potassium fertilization $\left(100 \mathrm{~kg} \mathrm{~K} \cdot \mathrm{ha}^{-1}\right.$, in the form of $40 \%$ potassium chloride $(\mathrm{KCl})$ was applied on all plots. The potassium dose met the nutrient demand of the tested varieties. Phosphorus fertilization was not applied because it had been calculated that the amount of phosphorus present 
Table 1. Selected physical and chemical properties of soil before experiment establishment and chemical composition of municipal sewage sludge used.

\begin{tabular}{|c|c|c|c|c|}
\hline \multirow{2}{*}{ Parameter } & \multirow{2}{*}{ Unit } & \multicolumn{2}{|c|}{ Content in the soil layer } & \multirow{2}{*}{$\begin{array}{c}\text { Content in } \\
\text { sewage sludge }\end{array}$} \\
\hline & & $0-20 \mathrm{~cm}$ & $20-40 \mathrm{~cm}$ & \\
\hline Fraction $2-0.05 \mathrm{~mm}^{*}$ & \multirow{3}{*}{$\%$} & 32 & 23 & - \\
\hline Fraction $0.05-0.002 \mathrm{~mm}$ & & 39 & 45 & - \\
\hline Fraction $<0.002 \mathrm{~mm}$ & & 29 & 32 & - \\
\hline $\mathrm{pH}_{\mathrm{KCl}}$ & & 6.29 & 6.44 & 6.04 \\
\hline $\mathrm{CaCO}_{3}$ & $\%$ & $<1$ & $<1$ & - \\
\hline Organic matter & $\mathrm{g} \cdot \mathrm{kg}^{-1} \mathrm{DM}$ & 14.5 & 14.1 & 594.0 \\
\hline Available phosphorus (P) & \multirow{3}{*}{$\mathrm{mg} \cdot \mathrm{kg}^{-1} \mathrm{DM}$} & 30.9 & 29.6 & 2.25 \\
\hline Available potassium $(\mathrm{K})$ & & 91.3 & 60.6 & $\mathrm{Bdl}^{* *}$ \\
\hline Available magnesium (Mg) & & 27.6 & 24.6 & 0.28 \\
\hline Total chromium $(\mathrm{Cr})$ & \multirow{6}{*}{$\mathrm{mg} \cdot \mathrm{kg}^{-1} \mathrm{DM}$} & 9.66 & 9.89 & 25.4 \\
\hline Total nickel (Ni) & & 6.39 & 6.31 & 14.8 \\
\hline Total copper $(\mathrm{Cu})$ & & 3.20 & 3.60 & 111 \\
\hline Total zinc $(\mathrm{Zn})$ & & 31.97 & 31.00 & 1005 \\
\hline Total cadmium $(\mathrm{Cd})$ & & $<0.27$ & $<0.27$ & 2.35 \\
\hline Total lead (Pb) & & 13.67 & 13.63 & 42.9 \\
\hline
\end{tabular}

"Clay loam (CL) $\quad{ }^{* *}$ Below detection level

in the sewage sludge was sufficient to meet the plant demand for this component (depending on the sewage sludge dose, from 125 to $750 \mathrm{~kg} \cdot \mathrm{ha}^{-1}$ of total phosphorus was applied). The heavy metal content determined in the sewage sludge did not exceed acceptable values for using municipal sewage sludge for reclamation (Table 1) $[16,27]$. Sewage sludge used in the experiment contained no pathogenic bacteria of the genus Salmonella and live eggs of intestinal parasites Ascaris sp., Trichuris sp., and Toxocara sp. [16].

\section{Scheme and Conditions of Conducting the Field Experiment}

The two-factor field experiment was set up in the split-plot system in triplicate. The area of the plot was $14.4 \mathrm{~m}^{2}$. The dose of municipal sewage sludge was the first experimental factor. The experimental design comprised five treatments: 1) control, 2) $10 \mathrm{Mg} \mathrm{DM}$, 3) $20 \mathrm{Mg} \mathrm{DM}$, 4) $40 \mathrm{Mg} \mathrm{DM}$, and 5) $60 \mathrm{Mg} \mathrm{DM}$ of municipal sewage sludge per hectare. Two varieties of Jerusalem artichoke (Helianthus tuberosus L.) - Rubik (purple tubers) and Albik (yellow tubers) - were the second experimental factor. Jerusalem artichoke tubers were planted in May 2008, with spacing $28 \times 75 \mathrm{~cm}$ (68 tubers of Jerusalem artichoke were planted at one time in each experimental plot). Cultivation of the Jerusalem artichoke varieties with varied doses of sewage sludge was conducted in 2008-13.
In the first year of vegetation, agricultural practices (manual weeding, soil scarification using a hoe) were performed several times, depending on need. In the second and later years of vegetation, these practices were not necessary owing to strong shadowing of soil. Every year at the end of plant vegetation (at the turn of October and November), aboveground parts (stems and leaves) were harvested. Aboveground parts of Jerusalem artichoke plants were harvested from tubers planted in the first year of their vegetation.

\section{Weather Conditions}

Mean air temperature and rainfall during the experiment in 2008-13 were based on data from the Agrometeorological Observatory of University of Life Sciences in Lublin. The average air temperature during six years of Jerusalem artichoke vegetation was $14.6^{\circ} \mathrm{C}$ (being higher than the average of the long-term period by $1.4^{\circ} \mathrm{C}$ ), while total precipitation exceeded the average by $36 \mathrm{~mm}$. However, each of the years of the experiment were characterized by considerable variability. The complete characteristics of weather conditions were described in our previous paper [29].

Determining Yield, Heavy Metal Content, and Soil Enzymatic Activity

Each year, varieties of Jerusalem artichoke were harvested using hand tools in autumn, at the turn of 
October and November. After the harvest the plant material from each plot (replication) was dried and all aerial biomass from a plot was chopped in a Bear Cat 70080 s-8HP chipper shredder (Colorado, USA). Then, 500 -g subsamples from each plot were taken for chemical analysis and dried at $105^{\circ} \mathrm{C}$ for $72 \mathrm{~h}$ in a dryer with forced air circulation. After drying, the air-dry mass of energy crops, and then the yield of air-dry mass was determined in accordance with the commonly adopted methodology of field experiments [30]. Each year, samples of the analyzed crops were subjected to dry mineralization in a muffle furnace at $550^{\circ} \mathrm{C}$ [30-31]. After incineration of the organic matter and digestion in a mixture of $\mathrm{HNO}_{3}$ and $\mathrm{HClO}_{4}(3: 2, v / v)$, the contents of elements determined in the soil and in the sewage sludge were similar to the total contents [30]. Each year, after mineralization of the plant and soil material, contents of $\mathrm{Cr}, \mathrm{Ni}, \mathrm{Cu}, \mathrm{Zn}, \mathrm{Cd}$, and $\mathrm{Pb}$ were determined using an ICP-OES emission spectrometer [32].

Soil $\mathrm{pH}$ in $1 \mathrm{~mol} \cdot \mathrm{dm}^{-3} \mathrm{KCl}$ was determined using the potentiometric method, available $\mathrm{P}$ and $\mathrm{K}$ content was determined after the Egner-Riehm method, and available $\mathrm{Mg}$ content was determined according to the Schachtschabel method [30]. Available phosphorus and potassium compounds were extracted from the soil using a solution of calcium lactate acidified with hydrochloric acid to $\mathrm{pH} 3.55$. Available magnesium was extracted from the soil using a solution of calcium chloride. In the soil filtrate, phosphorus was determined colorimetrically, while potassium and magnesium were measured by ASA method. Each year during the vegetation season, in May, soil samples were collected from each plot (each repetition) from $0-20 \mathrm{~cm}$ depth, using Egner's soil probe sampler, in order to assess the enzymatic activity of the soil. Analyses of the soil also involved determining the activities of enzymes, which play a key role in the stable mineralization of organic matter and in supplying nutrients to the roots of energy crops. The activity of the studied enzymes was determined using the following methods: of dehydrogenases with a TTC (triphenyl tetrazolium chloride) substrate using the Thalmann method [33], of acid phosphatase and alkaline phosphatase using the Tabatabai and Bremner method [34], of urease using the Zantua and Bremner method [35], and of protease using the Ladd and Butler method [36]. The activity of dehydrogenases was given in $\mathrm{cm}^{3} \mathrm{H}_{2}$, necessary for reducing TTC to TFP (triphenyl phormosan); of phosphatases in mmols of $\mathrm{p}$-nitrophenol (PNP) produced from sodium 4-nitrophenylphosphate; urease in $\mathrm{mg} \mathrm{N}-\mathrm{NH}_{4}^{+}$generated from hydrolyzed urea; and protease in $\mathrm{mg}$ tyrosine developed from sodium caseinate. The results of the analyses of enzymatic activity of the soil were presented in the paper as means for the six years of studies, i.e., for the 2008-13 period.

\section{Analytical Quality Control}

The ICP-OES Optima 7300 DV atomic emission spectrometer from Perkin Elmer Company was used for determining heavy metals in plant and soil materials. Determinations in each of the analyzed samples were carried out in three replications. A quantitative analysis mode was used for the data acquisition of the samples. The scanning of each single sample was repeated three times to gather reasonably good results. During measurements, care was taken to avoid the memory effect and therefore a washout time of $0.5 \mathrm{~min}$ was used. The accuracy of the analytical methods was verified based on certified reference materials: CRM IAEA/V - 10 Hay (International Atomic Energy Agency), CRM - CD281 - Rey Grass (Institute for Reference Materials and Measurements), and CRM023-050 - Trace Metals Sandy Loam 7 (RT Corporation).

\section{Computations and Statistical Analysis of the Results}

Heavy metal content in the yield of the above-ground parts of Jerusalem artichoke, due to cultivation of two varieties and variability of conditions in individual years, is presented in the form of a multi-year (2008-13) weighted mean. Heavy metal uptake (U) was calculated annually, as the product of dry matter yield (Y) and heavy metal content (C), according to the formula: $U=Y \cdot C$. Heavy metal uptake was expressed in $\mathrm{g} \cdot \mathrm{ha}^{-1}$. Heavy metal uptake is presented as the total from the entire research period (2008-13). The balance (B) of heavy metals was calculated from the difference between the amount of metals applied (A) with the dose of sewage sludge in 2008, and the amount of metals uptaken (U) with plant yield, according to the formula: $\mathrm{B}=\mathrm{A}-\mathrm{U}$. The simplified balance did not take into account the inflow of metals with precipitation or leaching of heavy metals deep into the soil profile. Recovery of heavy metals presented in the balance is the percentage share of the uptake of heavy metals by the varieties in relation to the amount introduced to soil along with sewage sludge.

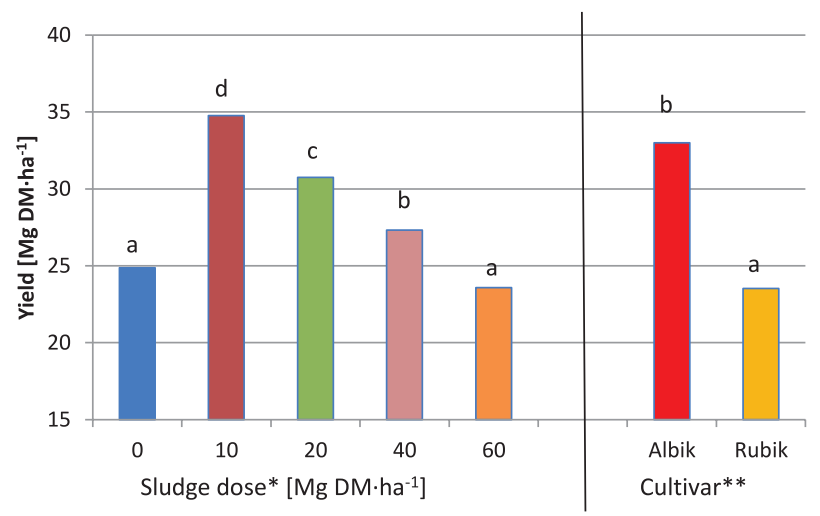

Fig. 1. The yield of underground biomass of Jerusalem artichokes (on average, from the research years 2008-13) under the experimental factors of sewage sludge dose and cultivar).

*The sludge dose's means denoted by different letters differ statistically at a level of $\mathrm{p}=0.05$.

**The cultivar's means denoted by different letters differ statistically at a level of $\mathrm{p}=0.05$. 
The statistical analysis of the research results was carried out using the Statistica software package. Statistical significance of the analyzed sources of variability was assessed using a two-factor analysis of variance. Significance of differences between mean values was verified using t-Tukey's test at a significance level of $p=0.05$. For selected parameters, values of Pearson's linear correlation coefficients (r) were computed, at a significance level of $p \leq 0.05$. 5\% was adopted as maximum dispersion between measurements in chemical analysis.

\section{Results}

\section{Crop Yield}

The yield of Jerusalem artichoke grown on municipal sewage sludge varied and depended on variety, sewage sludge dose, and vegetation seasons (Fig. 1, Table 2).

Fig. 1 shows the mean yield of two Jerusalem artichoke varieties obtained in the multi-year period 2008-13, which, depending on the dose of sewage sludge, ranged between 20.1 and $41.3 \mathrm{Mg} \mathrm{DM} \cdot \mathrm{ha}^{-1}$. The yield of Albik, depending on the dose of sewage sludge, was $24 \%$ to $56 \%$

Table 2. Yield of varieties of Jerusalem artichoke tested in the following years of the study $\left(\mathrm{Mg} \mathrm{DM} \cdot \mathrm{ha}^{-1}\right)$.

\begin{tabular}{|c|c|c|c|c|c|c|}
\hline \multirow{2}{*}{ Treatments } & \multicolumn{6}{|c|}{ Year } \\
\hline & 2008 & 2009 & 2010 & 2011 & 2012 & 2013 \\
\hline $\begin{array}{l}\text { Sludge dose } \\
\left(\mathrm{Mg} \mathrm{DM} \cdot \mathrm{ha}^{-1}\right)\end{array}$ & \multicolumn{6}{|c|}{ 'Rubik' } \\
\hline 0 & 12.5 & 20.5 & 15.5 & 29.4 & 19.6 & 35.6 \\
\hline 10 & 13.2 & 20.0 & 18.1 & 44.0 & 31.6 & 42.6 \\
\hline 20 & 15.4 & 19.6 & 17.3 & 33.5 & 27.6 & 41.3 \\
\hline 40 & 10.0 & 17.9 & 16.0 & 22.9 & 20.8 & 40.4 \\
\hline 60 & 9.4 & 17.3 & 12.2 & 22.7 & 24.9 & 34.1 \\
\hline Mean & 12.1 & 19.1 & 15.8 & 30.5 & 24.9 & 38.8 \\
\hline $\mathrm{CV}(\%)^{*}$ & 19.6 & 8.0 & 14.2 & 30.4 & 19.2 & 11.4 \\
\hline $\begin{array}{c}\text { Sludge dose } \\
\left(\mathrm{Mg} \mathrm{DM} \cdot \mathrm{ha}^{-1}\right)\end{array}$ & \multicolumn{6}{|c|}{ 'Albik' } \\
\hline 0 & 11.6 & 27.6 & 17.5 & 38.9 & 30.6 & 39.1 \\
\hline 10 & 11.3 & 24.7 & 19.9 & 62.0 & 67.5 & 62.3 \\
\hline 20 & 14.2 & 23.5 & 25.7 & 54.0 & 35.0 & 61.8 \\
\hline 40 & 16.8 & 21.7 & 22.2 & 57.6 & 30.6 & 51.0 \\
\hline 60 & 13.3 & 21.6 & 18.7 & 40.4 & 28.0 & 40.3 \\
\hline Mean & 13.5 & 23.8 & 20.8 & 50.6 & 38.3 & 50.9 \\
\hline $\mathrm{CV}(\%)^{*}$ & 16.6 & 10.5 & 15.5 & 25.5 & 42.0 & 21.7 \\
\hline $\begin{array}{l}\text { Sludge dose } \\
\left(\mathrm{Mg} \mathrm{DM} \cdot \mathrm{ha}^{-1}\right)\end{array}$ & \multicolumn{6}{|c|}{ Mean for dose of the sewage sludge } \\
\hline 0 & 12.0 & 24.1 & 16.5 & 34.1 & 25.1 & 37.4 \\
\hline 10 & 12.3 & 22.4 & 19.0 & 53.0 & 49.5 & 52.4 \\
\hline 20 & 14.8 & 21.5 & 21.5 & 43.7 & 31.3 & 51.6 \\
\hline 40 & 13.4 & 19.8 & 19.1 & 40.3 & 25.7 & 45.7 \\
\hline 60 & 11.4 & 19.5 & 15.5 & 31.6 & 26.4 & 37.2 \\
\hline LSD for dose ${ }^{* *}$ & 1.2 & 1.4 & 1.0 & 9.0 & 4.9 & 7.1 \\
\hline LSD for species & 0.8 & 1.0 & 0.8 & 7.6 & 3.9 & 2.3 \\
\hline LSD for interaction & 1.7 & n.s. ${ }^{* * *}$ & 1,8 & n.s. & 8.6 & 7.9 \\
\hline
\end{tabular}

${ }^{*}$ Variability coefficient

${ }^{* *}$ Least significant differences

${ }^{* * *}$ Not significant 
Table 3. Weighted average of heavy metals content in varieties of Jerusalem artichoke $\left(\mathrm{mg} \cdot \mathrm{kg}^{-1} \mathrm{DM}\right)$.

\begin{tabular}{|c|c|c|c|c|c|c|}
\hline Treatments & $\mathrm{Cr}$ & $\mathrm{Ni}$ & $\mathrm{Cu}$ & $\mathrm{Zn}$ & $\mathrm{Cd}$ & $\mathrm{Pb}$ \\
\hline $\begin{array}{l}\text { Sludge dose } \\
\left(\mathrm{Mg} \mathrm{DM} \cdot \mathrm{ha}^{-1}\right)\end{array}$ & \multicolumn{6}{|c|}{ 'Rubik' } \\
\hline 0 & 0.17 & 0.23 & 1.10 & 15.27 & 0.08 & 0.29 \\
\hline 10 & 0.22 & 0.28 & 1.77 & 18.27 & 0.10 & 0.34 \\
\hline 20 & 0.30 & 0.52 & 2.54 & 21.08 & 0.13 & 0.37 \\
\hline 40 & 0.34 & 0.77 & 3.68 & 23.11 & 0.15 & 0.45 \\
\hline 60 & 0.41 & 1.03 & 4.33 & 26.90 & 0.25 & 0.56 \\
\hline Mean & 0.29 & 0.57 & 2.68 & 20.92 & 0.14 & 0.40 \\
\hline $\mathrm{CV}(\%)^{*}$ & 32.7 & 56.1 & 48.0 & 21.1 & 46.0 & 26.9 \\
\hline $\begin{array}{c}\text { Sludge dose } \\
\left(\mathrm{Mg} \mathrm{DM} \cdot \mathrm{ha}^{-1}\right)\end{array}$ & \multicolumn{6}{|c|}{ 'Albik' } \\
\hline 0 & 0.13 & 0.25 & 1.23 & 14.67 & 0.09 & 0.33 \\
\hline 10 & 0.16 & 0.37 & 1.59 & 18.02 & 0.10 & 0.40 \\
\hline 20 & 0.22 & 0.56 & 2.09 & 20.63 & 0.14 & 0.41 \\
\hline 40 & 0.31 & 0.72 & 3.32 & 22.66 & 0.18 & 0.49 \\
\hline 60 & 0.40 & 0.88 & 3.93 & 43.89 & 0.27 & 0.65 \\
\hline Mean & 0.24 & 0.56 & 2.43 & 23.97 & 0.15 & 0.45 \\
\hline $\mathrm{CV}(\%)^{*}$ & 42.5 & 42.8 & 44.7 & 45.9 & 44.8 & 26.9 \\
\hline $\begin{array}{c}\text { Sludge dose } \\
\left(\mathrm{Mg} \mathrm{DM} \cdot \mathrm{ha}^{-1}\right)\end{array}$ & \multicolumn{6}{|c|}{ Mean for dose of the sewage sludge } \\
\hline 0 & 0.15 & 0.24 & 1.16 & 14.97 & 0.08 & 0.31 \\
\hline 10 & 0.19 & 0.32 & 1.68 & 18.14 & 0.10 & 0.37 \\
\hline 20 & 0.26 & 0.54 & 2.31 & 20.85 & 0.13 & 0.39 \\
\hline 40 & 0.32 & 0.75 & 3.50 & 22.89 & 0.16 & 0.47 \\
\hline 60 & 0.40 & 0.95 & 4.13 & 35.39 & 0.26 & 0.60 \\
\hline LSD for $\operatorname{dos} \mathrm{e}^{* *}$ & 0.01 & 0.05 & 0.38 & 2.25 & 0.02 & 0.02 \\
\hline LSD for species & 0.01 & n.s. & 0.12 & 1.00 & 0.01 & 0.01 \\
\hline LSD for interaction & 0.02 & 0.07 & 0.42 & 2.75 & n.s. ${ }^{* * *}$ & n.s. \\
\hline
\end{tabular}

*Variability coefficient

${ }^{* *}$ Least significant differences

****Not significant

higher than that of Rubik. The highest yield of the tested varieties of Jerusalem artichoke was obtained in the treatment where $10 \mathrm{Mg} \mathrm{DM} \cdot \mathrm{ha}^{-1}$ sewage sludge had been applied, and the lowest yield was obtained at the highest dose of sewage sludge, i.e., $60 \mathrm{Mg} \mathrm{DM} \cdot \mathrm{ha}^{-1}$. The dose of $10 \mathrm{Mg} \mathrm{DM} \cdot \mathrm{ha}^{-1}$ sewage sludge caused an increase in the mean yield of the Rubik and Albik varieties by more than $27 \%$ and $49 \%$, respectively, in relation to the control treatment (Fig. 1). The research shows that, compared to Rubik, Albik responded with a higher increase in yield under the influence of sewage sludge.

The analysis of the correlation coefficient value showed important correlations between the dose of sewage sludge and the yield of Rubik $\left(r_{(p=0.022)}=-0.58\right)$, whereas for
Albik such a correlation was not observed. The amount of metals $(\mathrm{Cr}, \mathrm{Ni}, \mathrm{Cu}, \mathrm{Zn}, \mathrm{Cd}$, and $\mathrm{Pb}$ ) introduced with the sewage sludge dose was also significantly correlated with the mean yield of Rubik $\left(\mathrm{r}_{(\mathrm{p}=0.022)}=-0.58\right)$. In the case of Albik such a correlation was not observed.

The sewage sludge (applied once) exerted a significant effect on the amount of yield of the Jerusalem artichoke varieties in subsequent years of research (Table 2).

The lowest yields of the studied varieties were obtained in the first year of the research, which resulted mainly from the shorter vegetation period and the necessity for the plant to adapt and put down roots. Also, over time, the sewage sludge used has a positive effect on plants by releasing nutrients and improving the soil structure. 
Higher yields of the tested Jerusalem artichoke varieties were obtained in the second and successive years of research as compared to the first vegetation year.

The highest yields of Rubik were obtained in the sixth year of research. Depending on the dose of sewage sludge, the amount of yield of this variety was from 2.7 to 4.0 times higher in 2013 than the yield obtained in the first year of vegetation.

Yields of Albik also increased gradually in successive years of vegetation. Generally, the highest yields of this variety were obtained in 2011-13. Depending on the dose of sewage sludge, the amount of yield of Albik was from 3.0 to 5.5 times higher in 2013 than the yield obtained in the first year of vegetation.

The conducted research confirms the significant correlations between sewage sludge dose (and heavy metals introduced with it) and the yield of the tested Jerusalem artichoke varieties only in 2009 $\left(\mathrm{r}_{(\mathrm{p}=0.003)}=-0.52\right)$. The above-mentioned correlation was not observed in the remaining years of Jerusalem artichoke cultivation.

\section{Heavy Metal Content in the Jerusalem Artichoke Varieties}

The contents of $\mathrm{Cr}, \mathrm{Ni}, \mathrm{Cu}, \mathrm{Zn}, \mathrm{Cd}$, and $\mathrm{Pb}$ in the municipal sewage sludge were, respectively, more than 1.6, 1.3, 33.6, 30.4, 7.7, and 2.1 times higher as compared to the soil surface layer (Table 1). The chemical composition of the sewage sludge indicates that this waste was a potential source of heavy metals in the soil for the Jerusalem artichoke varieties.

It has been shown that, apart from the doses of sewage sludge, properties of the varieties were a factor that significantly modified the heavy metal content in the above-ground parts of this species (Table 3). Under control conditions, there were significant differences in the content of heavy metals between the tested varieties of Jerusalem artichoke. The control, where sewage sludge was not applied, was found to have the lowest content of the studied metals in the tested varieties, as compared to the treatments where sewage sludge was applied (Table 3). Application of increasing doses of sewage sludge in the amount of 10 to $60 \mathrm{Mg} \mathrm{DM} \cdot \mathrm{ha}^{-1}$ had a significant effect on the increase in heavy metal content in the tested varieties. At the highest dose of sewage sludge, increases in metal content in Rubik amounted to: $147 \%$ for $\mathrm{Cr}, 347 \%$ for $\mathrm{Ni}$, $295 \%$ for $\mathrm{Cu}, 76 \%$ for $\mathrm{Zn}, 205 \%$ for $\mathrm{Cd}$, and $94 \%$ for $\mathrm{Pb}$ in relation to the control. The highest increase in the amount of heavy metals in Albik reached, respectively: 194\% for Cr, $249 \%$ for $\mathrm{Ni}, 219 \%$ for $\mathrm{Cu}, 199 \%$ for $\mathrm{Zn}, 206 \%$ for $\mathrm{Cd}$, and $97 \%$ for $\mathrm{Pb}$ in relation to the control.

In terms of increasing content, the metals were arranged in the following order for Rubik: $\mathrm{Ni}>\mathrm{Cu}>\mathrm{Cd}>\mathrm{Cr}>\mathrm{Pb}>\mathrm{Zn}$. In the case of Albik, the order was as follows: $\mathrm{Ni}>\mathrm{Cu}>\mathrm{Cd}>\mathrm{Zn}>\mathrm{Cr}>\mathrm{Pb}$.

In the case of the control treatment, there were no significant differences in the heavy metal content in the tested varieties of Jerusalem artichoke. The applied doses of sewage sludge, in the amount of $10-60 \mathrm{Mg} \mathrm{DM} \cdot \mathrm{ha}^{-1}$, brought about diversity in the content of heavy metals in the tested varieties of Jerusalem artichoke. At the highest dose of sewage sludge (60 Mg DM $\left.\cdot \mathrm{ha}^{-1}\right)$, Rubik had a higher content of $\mathrm{Cu}$ and Ni than Albik, which was found to have a higher content of $\mathrm{Zn}, \mathrm{Cd}$, and $\mathrm{Pb}$. $\mathrm{Cr}$ content in both tested varieties of Jerusalem artichoke was not significantly varied. The research shows that increasing doses of sewage sludge differentiated the content of heavy metals in the tested Jerusalem artichoke varieties.

The linear correlation analysis indicates strong correlations between the load of metals $(\mathrm{Cr}, \mathrm{Ni}, \mathrm{Cu}$, $\mathrm{Zn}, \mathrm{Cd}, \mathrm{Pb}$ ) introduced with the dose of sewage sludge and the content of these metals in the varieties $\left(\mathrm{r}_{(\mathrm{p}<0.000)}=0.81-0.96\right)$. The correlation analysis also indicated a significant relationship between yield and $\mathrm{Cr}$ content in the Jerusalem artichoke varieties $\left(r_{(p=0.019)}=-0.43\right)$. No significant correlation between yield and $\mathrm{Ni}, \mathrm{Cu}, \mathrm{Zn}, \mathrm{Cd}, \mathrm{Pb}$ content in the Jerusalem artichoke varieties were observed.

Significant relationships between the mean yield of Rubik and $\mathrm{Cd}$ and $\mathrm{Ni}$ content in this variety $\left(r_{(p=0.030)}=-0.56\right.$ and $r_{(p=0.015)}=-0.62$ respectively) were observed. However, the linear correlation analysis did not show significant relationships between the mean yield of Albik and the content of heavy metals in this variety.

\section{Uptake of Heavy Metals by the Jerusalem Artichoke Varieties}

The uptake of heavy metals by Jerusalem artichoke was calculated annually as the product of dry matter yield and heavy metal content in these varieties. However, heavy metal uptakes are presented as the total (sum) from the entire research period, that is from 2008-13 (Table 4). The amount of heavy metals taken up from the control and treatments fertilized with sewage sludge depended on the yield (Table 2) and the content of metals in the Jerusalem artichoke varieties in the following years of the experiment. In the control treatment (not fertilized with sewage sludge), considerable diversity in $\mathrm{Ni}, \mathrm{Cu}, \mathrm{Zn}$, $\mathrm{Cd}$, and $\mathrm{Pb}$ uptake by Jerusalem artichoke varieties was observed. It was established that Albik took up more of these metals than Rubik. No significant diversity in the amount of $\mathrm{Cr}$ taken up by tested varieties was observed (Table 4). Compared to the control, applying increasing doses of sewage sludge had a significant effect on the increase in metal uptake by the yield of Jerusalem artichoke varieties. Research shows that at the highest dose of sewage sludge Albik took up significantly more metals than Rubik.

The highest $\mathrm{Cr}, \mathrm{Ni}, \mathrm{Zn}, \mathrm{Cd}$, and $\mathrm{Pb}$ uptake with the yield of Albik was observed at the highest dose of sewage sludge (60 Mg DM $\left.\cdot \mathrm{ha}^{-1}\right)$, and $\mathrm{Cu}$ at the dose of $40 \mathrm{Mg}$ $\mathrm{DM} \cdot \mathrm{ha}^{-1}$. Increases in the uptake of the above-mentioned metals from sewage sludge by Albik were, respectively, more than $189 \%, 243 \%, 193 \%, 200 \%, 94 \%$, and (for $\mathrm{Cu}$ ) $213 \%$ higher compared to the control treatment. Increases in the uptake of $\mathrm{Cr}, \mathrm{Ni}, \mathrm{Cu}, \mathrm{Zn}, \mathrm{Cd}$, and $\mathrm{Pb}$ by Rubik, 
Table 4 . Heavy metals uptake by varieties of Jerusalem artichoke $\left(\mathrm{g} \cdot \mathrm{ha}^{-1}\right)$.

\begin{tabular}{|c|c|c|c|c|c|c|}
\hline Treatments & $\mathrm{Cr}$ & $\mathrm{Ni}$ & $\mathrm{Cu}$ & $\mathrm{Zn}$ & $\mathrm{Cd}$ & $\mathrm{Pb}$ \\
\hline $\begin{array}{l}\text { Sludge dose } \\
\left(\mathrm{Mg} \mathrm{DM} \cdot \mathrm{ha}^{-1}\right)\end{array}$ & \multicolumn{6}{|c|}{ 'Rubik' } \\
\hline 0 & 22.1 & 30.6 & 146.2 & $2,036.5$ & 11.0 & 38.2 \\
\hline 10 & 37.7 & 46.8 & 299.8 & $3,100.5$ & 16.2 & 58.5 \\
\hline 20 & 46.9 & 81.3 & 395.4 & $3,268.0$ & 19.9 & 57.0 \\
\hline 40 & 43.2 & 98.9 & 470.6 & $2,952.6$ & 19.3 & 57.8 \\
\hline 60 & 49.4 & 123.7 & 521.7 & $3,240.5$ & 30.2 & 67.0 \\
\hline Mean & 39.9 & 76.3 & 366.7 & $2,919.6$ & 19.3 & 55.7 \\
\hline $\mathrm{CV}(\%)^{*}$ & 28.4 & 47.3 & 40.2 & 18.7 & 36.5 & 21.8 \\
\hline $\begin{array}{c}\text { Sludge dose } \\
\left(\mathrm{Mg} \mathrm{DM} \cdot \mathrm{ha}^{-1}\right)\end{array}$ & \multicolumn{6}{|c|}{ 'Albik' } \\
\hline 0 & 22.3 & 41.4 & 203.2 & $2,422.0$ & 14.4 & 54.0 \\
\hline 10 & 39.1 & 90.3 & 391.3 & $4,440.3$ & 25.0 & 99.0 \\
\hline 20 & 46.8 & 121.0 & 448.1 & $4,431.4$ & 29.0 & 88.2 \\
\hline 40 & 62.3 & 143.8 & 665.2 & $4,538.5$ & 35.7 & 97.5 \\
\hline 60 & 64.5 & 142.3 & 637.1 & $7,108.4$ & 43.4 & 104.9 \\
\hline Mean & 47.0 & 107.8 & 469.0 & $4,588.1$ & 29.5 & 88.7 \\
\hline $\mathrm{CV}(\%)^{*}$ & 35.8 & 37.4 & 38.7 & 35.2 & 36.0 & 24.4 \\
\hline $\begin{array}{c}\text { Sludge dose } \\
\left(\mathrm{Mg} \mathrm{DM} \cdot \mathrm{ha}^{-1}\right)\end{array}$ & \multicolumn{6}{|c|}{ Mean for dose of the sewage sludge } \\
\hline 0 & 22.2 & 36.0 & 174.7 & $2,229.3$ & 12.7 & 46.1 \\
\hline 10 & 38.4 & 68.5 & 345.5 & $3,770.4$ & 20.6 & 78.8 \\
\hline 20 & 46.9 & 101.1 & 421.7 & $3,849.7$ & 24.5 & 72.6 \\
\hline 40 & 52.8 & 121.3 & 567.9 & $3,745.6$ & 27.5 & 77.6 \\
\hline 60 & 56.9 & 133.0 & 579.4 & $5,174.4$ & 36.8 & 85.9 \\
\hline LSD for dose $\mathrm{e}^{* *}$ & 4.0 & 8.7 & 64.0 & 341.7 & 3.2 & 7.0 \\
\hline LSD for species & 2.2 & 3.0 & 23.6 & 265.1 & 1.7 & 5.5 \\
\hline LSD for interaction & 5.3 & 9.9 & 74.0 & 592.7 & 4.2 & n.s. ${ }^{* * *}$ \\
\hline
\end{tabular}

*Variability coefficient

${ }^{* *}$ Least significant differences

**** Not significant

at the highest dose of sewage sludge, amounted to, respectively, over $123 \%, 304 \%, 256 \%, 59 \%, 174 \%$, and $75 \%$ compared to the control treatment. Analysis of the percentage increase in heavy metal uptake indicates that Albik, under the influence of increasing doses of sewage sludge, took up more $\mathrm{Cr}, \mathrm{Zn}, \mathrm{Cd}$, and $\mathrm{Pb}$ than Rubik. Rubik responded with a higher percentage increase in the uptake of $\mathrm{Ni}$ and $\mathrm{Cu}$ than Albik.

When analyzing the amount of extracted metals, at the highest dose of sewage sludge $\left(60 \mathrm{Mg} \mathrm{DM} \cdot \mathrm{ha}^{-1}\right)$, it was established that Albik took up significantly more $\mathrm{Cr}$, $\mathrm{Ni}, \mathrm{Cu}, \mathrm{Zn}, \mathrm{Cd}$, and $\mathrm{Pb}$ than Rubik.

Depending on treatment, Albik took up more $\mathrm{Cr}$ (between 0.6 and 30\%) than Rubik. In the case of the other metals, Albik took up more of these elements (15-92\% for $\mathrm{Ni}, 13-41 \%$ for $\mathrm{Cu}, 18-119 \%$ for $\mathrm{Zn}, 31-85 \%$ for $\mathrm{Cd}$, and $41-69 \%$ for $\mathrm{Pb}$ ) as compared to Rubik. Larger amounts of heavy metals taken up by Albik were associated with a higher yield of this variety and a higher content of these elements compared to Rubik (Tables 2-3).

The research shows that the greatest differences in the amount of heavy metals taken up by the Jerusalem artichoke varieties were observed at doses of $40 \mathrm{Mg}$ $\mathrm{DM} \cdot \mathrm{ha}^{-1}$ for $\mathrm{Cr}$ and $\mathrm{Cd}, 10 \mathrm{Mg} \mathrm{DM} \cdot \mathrm{ha}^{-1}$ for $\mathrm{Ni}$ and $\mathrm{Pb}$, for $\mathrm{Cu}$ in the control treatment, and for $\mathrm{Zn}$ at a dose of $60 \mathrm{Mg} \mathrm{DM} \cdot \mathrm{ha}^{-1}$.

The correlation coefficient analysis showed significant correlations between the uptake of heavy metals by the 
Jerusalem artichoke varieties and the load of heavy metals introduced with the sewage sludge dose (from $\mathrm{r}_{(\mathrm{p}=0.016)}=$ 0.44 to $\left.r_{(p<0.000)}=0.83\right)$. The mean yield of the Jerusalem artichoke varieties was also correlated with the uptake of $\mathrm{Zn}$ and $\mathrm{Pb}$ by these varieties $\left(\mathrm{r}_{(\mathrm{p}=0.024)}=0.41\right.$ and $\mathrm{r}_{(\mathrm{p}<0.000)}$ $=0.66$, respectively). The experiment revealed significant correlations between the content of heavy metals in the Jerusalem artichoke varieties and the uptake of these heavy metals by the plants (from $r_{(p=0.081)}=0.32$ to $r_{(p<0.000)}$ $=0.89$ ). Comparing the amount of heavy metals taken up by Albik to the other plants, this variety can be classified as a hyperaccumulator.

\section{Simplified Balance of Heavy Metals}

By using municipal sewage sludge, considerable amounts of heavy metals were introduced to the soil. These heavy metals can be taken up by plants and pose a risk for the cultivation of edible plants. Cultivation of selected varieties of Jerusalem artichoke (as an energy crop with a high phytoextraction potential) may contribute to a considerable elimination of harmful elements from the substrate. Understanding the circulation of heavy metals in the soil-plant system, through a simplified balance, will allow us to assess the effectiveness of phytoextraction by using Jerusalem artichoke varieties.

The outcome of the balance of heavy metals depended on the amount of metals introduced with the sewage sludge and on the metal uptake with the yield of the varieties (Table 5). In control treatments where sewage sludge was not applied, the balance of all the heavy metals was negative. The negative value of the balance resulted from a lack of influx of metals to the substrate.

Application of heavy metals into the soil (with sewage sludge doses of $10,20,40$, and $60 \mathrm{Mg} \mathrm{DM} \cdot \mathrm{ha}^{-1}$ ) led to a positive balance. Such high influx of metals supplied with increasing doses of sewage sludge caused an increase in the amount of these metals in the soil. Uptake of heavy metals by the Jerusalem artichoke varieties was lower compared to amounts introduced with the sewage sludge.

The analysis of $\mathrm{Cd}$ balance for Albik, in the treatment with the lowest sewage sludge dose (10 $\left.\mathrm{Mg} \mathrm{DM} \cdot \mathrm{ha}^{-1}\right)$, showed a negative value. This balance indicates that cadmium was taken up by this variety in higher quantities compared to the quantity introduced with the organic waste dose $\left(10 \mathrm{Mg} \mathrm{DM} \cdot \mathrm{ha}^{-1}\right)$. The greatest balance difference was observed in treatments where the highest dose of sewage sludge was applied $\left(60 \mathrm{Mg} \mathrm{DM} \cdot \mathrm{ha}^{-1}\right)$. This difference resulted from the amount of heavy metals introduced to the soil.

Phytoremediation enables assessment of plant suitability for removal of metals from the substrate. The highest phytoremediation of metals was observed in treatments where the lowest dose of sewage sludge (i.e., $10 \mathrm{Mg} \mathrm{DM} \cdot \mathrm{ha}^{-1}$ ) was applied (Table 5). Subsequent doses of sewage sludge had an effect on the percentage reduction in phytoremediation of metals from the soil. The lowest phytoextraction was observed in treatments where the highest dose of sewage sludge was applied (60 $\left.\mathrm{Mg} \mathrm{DM} \cdot \mathrm{ha}^{-1}\right)$. The lowest phytoremediation was associated with the highest soil enrichment in heavy metals as well as with yielding and uptake of these metals by the Jerusalem artichoke varieties.

When assessing the phytoextraction effectiveness of the Jerusalem artichoke varieties, it was established that regardless of treatment, Albik phytoremediated more $\mathrm{Ni}, \mathrm{Cu}, \mathrm{Zn}, \mathrm{Cd}$, and $\mathrm{Pb}$ than Rubik. The higher phytoremediation of metals resulted from the higher yield and uptake of these elements by Albik. When analyzing phytoremediation of $\mathrm{Cr}$, it was established that the tested Jerusalem artichoke varieties used this element equally only at 10 and $20 \mathrm{Mg} \mathrm{DM} \cdot \mathrm{ha}^{-1}$ of this sludge. It was established that Albik, at higher doses of sewage sludge (40 and $60 \mathrm{Mg} \mathrm{DM} \cdot \mathrm{ha}^{-1}$ ), also used more of this element from the soil.

When comparing the percentage phytoremediation of heavy metals by Albik at the lowest dose of sewage sludge (10 Mg DM $\cdot \mathrm{ha}^{-1}$ ), the following order (from highest to lowest values) can be established: Cd (106\%), Ni (61\%), $\mathrm{Zn}(44 \%), \mathrm{Cu}(35 \%), \mathrm{Pb}(23 \%)$, and $\mathrm{Cr}$ (15\%). The order shows that Albik recovered $\mathrm{Cd}$ to the greatest extent, and Cr to the smallest.

\section{Soil Enzymatic Activity}

Soil enzymatic activity can be a sensitive parameter providing information about the state of chemical environmental pollution. A significant effect of the increasing doses of sewage sludge on the soil enzymatic activity was observed in the field experiment (Table 6). Control treatments were found to have the lowest soil enzymatic activity compared to treatments where sewage sludge was applied. Increasing doses of sewage sludge had a significant effect on the increase in the activity of the studied soil enzymes, which was associated with the amount of carbon substrates available for microorganisms and enzymes.

In treatments with Rubik at the highest dose of sewage sludge (60 $\mathrm{Mg} \mathrm{DM} \cdot \mathrm{ha}^{-1}$ ), the increase in soil enzymatic activity in the case of dehydrogenase, urease, proteases, phosphatase acid, and alkaline was, respectively, more than 3.1, 2.3, 2.2, 2.7, and 2.6 times higher than in the control treatment. In treatments with Albik the increase in soil enzymatic activity was, respectively, more than 3.0, 2.0, 2.1, 2.6, and 2.7 times higher than the control treatment. In the treatment with the highest sewage sludge dose, regardless of Jerusalem artichoke variety, dehydrogenase activity increased the most. Maximum doses of sewage sludge were least effective in stimulating the increase in urease and protease activities.

From the tested Jerusalem artichoke varieties, it was shown that Albik stimulated the activity of the studied enzymes more than Rubik. This probably resulted from the higher yield, content, and uptake of heavy metals from the soil.

The conducted research has also confirmed significant correlations between the activity of soil enzymes and the 
Table 5. Simplified balance of heavy metals after six years of research.

\begin{tabular}{|c|c|c|c|c|c|c|c|}
\hline \multirow{3}{*}{ Treatments } & Introduced & Uptake & Balance & \multirow{3}{*}{$\begin{array}{c}\text { Recovery } \\
\%\end{array}$} & Uptake & Balance & \multirow{3}{*}{$\begin{array}{c}\text { Recovery } \\
\%\end{array}$} \\
\hline & \multicolumn{3}{|c|}{$\mathrm{g} \cdot \mathrm{ha}^{-1}$} & & \multicolumn{2}{|c|}{$\mathrm{g} \cdot \mathrm{ha}^{-1}$} & \\
\hline & & \multicolumn{2}{|r|}{ 'Rubik' } & & \multicolumn{2}{|r|}{ 'Albik' } & \\
\hline Sludge dose $\left(\mathrm{Mg} \mathrm{DM} \cdot \mathrm{ha}^{-1}\right)$ & \multicolumn{7}{|c|}{$\mathrm{Cr}$} \\
\hline 0 & 0 & 22 & -22 & 0 & 22 & -22 & 0 \\
\hline 10 & 254 & 38 & 216 & 15 & 39 & 215 & 15 \\
\hline 20 & 508 & 47 & 461 & 9 & 47 & 461 & 9 \\
\hline 40 & 1,016 & 43 & 973 & 4 & 62 & 954 & 6 \\
\hline 60 & 1,524 & 49 & 1,475 & 3 & 65 & 1,459 & 4 \\
\hline Sludge dose $\left(\mathrm{Mg} \mathrm{DM} \cdot \mathrm{ha}^{-1}\right)$ & \multicolumn{7}{|c|}{$\mathrm{Ni}$} \\
\hline 0 & 0 & 31 & -31 & 0 & 41 & -41 & 0 \\
\hline 10 & 148 & 47 & 101 & 32 & 90 & 58 & 61 \\
\hline 20 & 296 & 81 & 215 & 27 & 121 & 175 & 41 \\
\hline 40 & 592 & 99 & 493 & 17 & 144 & 448 & 24 \\
\hline 60 & 888 & 124 & 764 & 14 & 142 & 746 & 16 \\
\hline Sludge dose $\left(\mathrm{Mg} \mathrm{DM} \cdot \mathrm{ha}^{-1}\right)$ & \multicolumn{7}{|c|}{$\mathrm{Cu}$} \\
\hline 0 & 0 & 146 & -146 & 0 & 203 & -203 & 0 \\
\hline 10 & 1,110 & 300 & 810 & 27 & 391 & 719 & 35 \\
\hline 20 & 2,220 & 395 & 1,825 & 18 & 448 & 1,772 & 20 \\
\hline 40 & 4,440 & 471 & 3,969 & 11 & 665 & 3,775 & 15 \\
\hline 60 & 6,660 & 522 & 6,138 & 8 & 637 & 6,023 & 10 \\
\hline Sludge dose $\left(\mathrm{Mg} \mathrm{DM} \cdot \mathrm{ha}^{-1}\right)$ & \multicolumn{7}{|c|}{$\mathrm{Zn}$} \\
\hline 0 & 0 & 2,036 & $-2,036$ & 0 & 2,422 & $-2,422$ & 0 \\
\hline 10 & 10,050 & 3,100 & 6,950 & 31 & 4,440 & 5,610 & 44 \\
\hline 20 & 20,100 & 3,268 & 16,832 & 16 & 4,431 & 15,669 & 22 \\
\hline 40 & 40,200 & 2,953 & 37,247 & 7 & 4,539 & 35,661 & 11 \\
\hline 60 & 60,300 & 3,240 & 57,060 & 5 & 7,108 & 53,192 & 12 \\
\hline Sludge dose $\left(\mathrm{Mg} \mathrm{DM} \cdot \mathrm{ha}^{-1}\right)$ & \multicolumn{7}{|c|}{$\mathrm{Cd}$} \\
\hline 0 & 0 & 11 & -11 & 0 & 14 & -14 & 0 \\
\hline 10 & 24 & 16 & 7 & 69 & 25 & -1 & 106 \\
\hline 20 & 47 & 20 & 27 & 42 & 29 & 18 & 62 \\
\hline 40 & 94 & 19 & 75 & 20 & 36 & 58 & 38 \\
\hline 60 & 141 & 30 & 111 & 21 & 43 & 98 & 31 \\
\hline Sludge dose $\left(\mathrm{Mg} \mathrm{DM} \cdot \mathrm{ha}^{-1}\right)$ & \multicolumn{7}{|c|}{$\mathrm{Pb}$} \\
\hline 0 & 0 & 38 & -38 & 0 & 54 & -54 & 0 \\
\hline 10 & 429 & 59 & 370 & 14 & 99 & 330 & 23 \\
\hline 20 & 858 & 57 & 801 & 7 & 88 & 770 & 10 \\
\hline 40 & 1,716 & 58 & 1,658 & 3 & 97 & 1,619 & 6 \\
\hline 60 & 2,574 & 67 & 2,507 & 3 & 105 & 2,469 & 4 \\
\hline
\end{tabular}


Table 6. Soil enzymatic activity (average from 2008-13).

\begin{tabular}{|c|c|c|c|c|c|}
\hline Treatments & $\begin{array}{l}\text { Dehydrogenase } \\
\text { activity }\end{array}$ & $\begin{array}{c}\text { Urease } \\
\text { activity }\end{array}$ & Protease activity & $\begin{array}{l}\text { Acid phosphatase } \\
\text { activity }\end{array}$ & $\begin{array}{l}\text { Alcaline phosphatase } \\
\text { activity }\end{array}$ \\
\hline & $\left(\mathrm{cm}^{3} \mathrm{H}_{2} \cdot \mathrm{kg}^{-1} \cdot \mathrm{d}^{-1}\right)$ & $\begin{array}{l}\left(\mathrm{mg} \mathrm{N}^{-\mathrm{NH}_{4}^{+}}\right. \\
\left.\cdot \mathrm{kg}^{-1} \cdot \mathrm{h}^{-1}\right)\end{array}$ & $\begin{array}{l}\text { (mg of tyrosine } \\
\quad \mathrm{kg}^{-1} \cdot \mathrm{h}^{-1} \text { ) }\end{array}$ & $\begin{array}{c}(\mathrm{mmol} \text { PNP } \\
\left.\cdot \mathrm{kg}^{-1} \cdot \mathrm{h}^{-1}\right)\end{array}$ & $\begin{array}{c}(\mathrm{mmol} \text { PNP } \\
\left.\cdot \mathrm{kg}^{-1} \cdot \mathrm{h}^{-1}\right)\end{array}$ \\
\hline $\begin{array}{c}\text { Sludge dose } \\
\left(\mathrm{Mg} \mathrm{DM} \cdot \mathrm{ha}^{-1}\right)\end{array}$ & \multicolumn{5}{|c|}{ 'Rubik' } \\
\hline 0 & 4.2 & 7.0 & 10.8 & 27.8 & 19.2 \\
\hline 10 & 5.2 & 10.9 & 13.5 & 33.2 & 21.8 \\
\hline 20 & 8.0 & 11.8 & 18.2 & 43.1 & 28.4 \\
\hline 40 & 11.5 & 16.0 & 26.8 & 101.6 & 67.9 \\
\hline 60 & 17.3 & 23.2 & 34.6 & 102.1 & 68.4 \\
\hline Mean & 9.2 & 13.8 & 20.8 & 61.6 & 41.1 \\
\hline $\mathrm{CV}(\%)^{*}$ & 53.9 & 42.1 & 44.4 & 57.7 & 57.6 \\
\hline $\begin{array}{c}\text { Sludge dose } \\
\left(\mathrm{Mg} \mathrm{DM} \cdot \mathrm{ha}^{-1}\right)\end{array}$ & \multicolumn{5}{|c|}{ 'Albik’ } \\
\hline 0 & 4.4 & 8.1 & 11.7 & 29.0 & 20.3 \\
\hline 10 & 5.4 & 11.7 & 14.2 & 35.2 & 23.4 \\
\hline 20 & 8.9 & 13.0 & 19.4 & 44.3 & 30.4 \\
\hline 40 & 12.3 & 17.4 & 28.1 & 105.3 & 69.5 \\
\hline 60 & 17.6 & 24.5 & 35.8 & 105.7 & 74.9 \\
\hline Mean & 9.7 & 14.9 & 21.8 & 63.9 & 43.7 \\
\hline $\mathrm{CV}(\%)^{*}$ & 51.5 & 39.5 & 43.0 & 57.9 & 58.3 \\
\hline $\begin{array}{c}\text { Sludge dose } \\
\left(\mathrm{Mg} \mathrm{DM} \cdot \mathrm{ha}^{-1}\right)\end{array}$ & \multicolumn{5}{|c|}{ Mean for dose of the sewage sludge } \\
\hline 0 & 4.3 & 7.5 & 11.3 & 28.4 & 19.7 \\
\hline 10 & 5.3 & 11.3 & 13.9 & 34.2 & 22.6 \\
\hline 20 & 8.4 & 12.4 & 18.8 & 43.7 & 29.4 \\
\hline 40 & 11.9 & 16.7 & 27.5 & 103.5 & 68.7 \\
\hline 60 & 17.4 & 23.9 & 35.2 & 103.9 & 71.6 \\
\hline LSD for dose $\mathrm{e}^{* *}$ & 1.6 & 1.6 & 3.3 & 19.3 & 13.2 \\
\hline LSD for species & 0.2 & 0.5 & 0.3 & 1.8 & 1.6 \\
\hline LSD for interaction & 1.7 & n.s. ${ }^{* * *}$ & n.s. & n.s. & n.s. \\
\hline
\end{tabular}

*Variability coefficient

*** Least significant differences

${ }^{* * *}$ Not significant

load of heavy metals introduced to soil with the sewage sludge dose $\left(\mathrm{r}_{(\mathrm{p}<0.000)}=0.91-0.98\right)$.

Aside from biogenes, organic colloids and soil microorganisms that influence soil enzymatic activity, substantial quantities of heavy metals were supplied to the soil profile with municipal sewage sludge (Table 5). The experiment showed strong correlations between the activity of soil enzymes and heavy metal content in plants $\left(\mathrm{r}_{(\mathrm{p}<0.000)}=0.65-0.95\right)$, and heavy metal uptake by plants (from $r_{(p=0,056)}=0.35$ to $\left.r_{(p<0.000)}=0.82\right)$. The research shows that soil enzymatic activity is strictly correlated with heavy metal content in the soil and in the plant, which is of considerable importance in phytoremediation processes.

\section{Discussion}

Owing to its high yield potential and resistance as well as tolerance to pollutants, Jerusalem artichoke can be used as a potential phytoextractor of heavy metals from soil [14-15, 37]. Jerusalem artichoke has been used at 
industrial waste landfills and mining areas as a remedial plant [14-15]. However, there is little information in scientific literature regarding research on using specific varieties of this species for phytoextraction of heavy metals from municipal sewage sludge.

\section{Yield of the Jerusalem Artichoke Varieties}

The high yield of Jerusalem artichoke presented in this research resulted from the fertilizer effect of municipal sewage sludge. The average yield of tested Jerusalem artichoke varieties obtained from the multiyear period from 20.1 to $41.3 \mathrm{Mg} \mathrm{DM} \cdot \mathrm{ha}^{-1}$. Such high yields of Jerusalem artichoke varieties are evidence of a positive response of this species to the applied sewage sludge, which finds confirmation in scientific literature [38-39]. The amount of yield obtained in the authors own research was comparable to the amount of yield obtained by Baldini et al. [10]. Scientific literature and the authors' own research indicate that the amount of Jerusalem artichoke yield depends on variety, soil, and climatic conditions, and on agrotechnical measures [10, 40]. Other studies have also shown that Jerusalem artichoke yield can be high and can reach even $30 \mathrm{Mg} \cdot \mathrm{ha}^{-1}$ [41]. The study conducted by Pakarinen et al. [11] showed that the amount of Jerusalem artichoke yield varied from 7 to 16 $\mathrm{Mg} \mathrm{DM} \cdot \mathrm{ha}^{-1}$ and was much lower than yields obtained in this research. The distinct diversity of the amount of yield of the Jerusalem artichoke varieties in respective years which was determined in this research finds confirmation in literature [42-43]. Our own research showed that the highest doses of sewage sludge $\left(60 \mathrm{Mg} \mathrm{DM} \cdot \mathrm{ha}^{-1}\right)$ decreased the yield of the Jerusalem artichoke varieties, and this resulted, among other things, from a large load of heavy metals. This research confirms that, under the influence of a high heavy metal content, Jerusalem artichoke growth and development were inhibited [14].

\section{Heavy Metal Content in Jerusalem Artichoke Varieties}

Chemical composition of Jerusalem artichoke depends on numerous factors, such as the date of harvest, variety, soil conditions, reaction, and type of pollutant $[3,14,44]$. Our own research showed that increasing doses of municipal sewage sludge had a considerable effect on the increase of heavy metal content in the tested varieties. It was also shown that properties of the varieties significantly modified the heavy metal content in the aboveground parts of this species. Our own research showed that Albik had higher $\mathrm{Zn}, \mathrm{Cd}$, and $\mathrm{Pb}$ contents than Rubik, whereas Rubik had a higher $\mathrm{Cu}$ and Ni contents. Other studies [14] have shown that Rubik grown on soil polluted with heavy metals accumulates substantial quantities of $\mathrm{Ni}, \mathrm{Mn}$, and $\mathrm{Zn}$ in the aboveground parts. Research conducted by Zhang et al. [37] confirmed that Jerusalem artichoke, among other reclamation crops, is characterized by a substantial ability to accumulate heavy metals from degraded soils. Research conducted by Zhang et al. [37] showed that Jerusalem artichoke is extremely suitable for $\mathrm{Cd}$ phytoremediation from chemically polluted soil. Further studies confirm that there is varietal diversity of Jerusalem artichoke in terms of Cd accumulation in tubers and stems [21, 45]. Research conducted by Chen et al. [21] suggests that Jerusalem artichoke can be grown at high $\mathrm{Cd}$ concentrations in the substrate. On account of intensive Cd transfer from the substrate to the aboveground parts, Jerusalem artichoke can be a potential candidate for phytoremediation of soils polluted with this metal [21]. Other studies [43] confirm that there are varietal differences in chemical composition under the influence of mineral fertilization of Jerusalem artichoke. Varied doses of mineral fertilization not only diversify the chemical composition of Jerusalem artichoke varieties, but they also influence the chemical composition of tubers of other plants, including potato [46]. Other studies [47-48] point to the possibility of using energy crops, plantations for eliminating pollutants from sewage or sewage sludge, and from chemically polluted soils.

\section{Uptake of Heavy Metals by the Aboveground Parts of Jerusalem Artichoke}

Larger amounts of heavy metals extracted by Albik can be explained by higher yielding and higher content of these metals, which is of great importance when selecting varieties for the process of phytoextraction of metals from organic waste [14]. Research conducted by Borkowska et al. [20] confirms that Jerusalem artichoke, among other energy crops, is suitable for phytoextraction of heavy metals from sewage sludge. The research conducted by Borkowska et al. [20] showed that among heavy metals, Cd was taken up by Jerusalem artichoke in significantly larger amounts compared to the amounts obtained in this research. Research conducted by Long et al. [49] also showed that there are differences in phytoextraction potential between Jerusalem artichoke varieties. For example NY5 variety had a higher phytoextraction potential than NY2 variety [49].

Research on the suitability of willow for remediation of sewage sludge showed that there are differences in heavy metal uptake between clones of the same species $[21,47]$, which is why not only selection of appropriate plant species but also selection of proper variety or clone appear to be important in heavy metals phytoextraction [21, 23, 47, 49].

\section{Balance}

Negative value of the balance in control treatments resulted from the simplified balance in which the supply of metals from precipitation was not taken into account. Phytoremediation can be used to assess the effectiveness of removing metals from the substrate. The research shows that, compared to Rubik, Albik cleaned the substrate more effectively. Research conducted by Laidlaw et al. [23] confirms that energy crops, including willow, can be 
used for phytoextraction of heavy metals from substrate polluted with heavy metals. The cited authors [23] showed that willow, out of all heavy metals, extracts cadmium from the substrate most efficiently. Our own research also shows that Jerusalem artichoke, as an energy crop, also efficiently extracts $\mathrm{Cd}$ from the substrate. Other research [3] confirms that Jerusalem artichoke, next to other plants, is a potential hyperaccumulator of heavy metals from chemically polluted soils. The use of a proper Jerusalem artichoke variety as a plant with substantial phytoextraction potential may improve the balance of heavy metals in the environment $[3,21,45]$.

\section{Soil Enzymatic Activity}

Soil enzymatic activity is a sensitive indicator of stress conditions in plants, and it serves for the assessment of the influence environmental factors have on plants [50]. Our own research confirms the stimulating effect of sewage sludge on soil enzymatic activity [51]. The increase in soil enzymatic activity can be explained primarily by the increase in the content of readily available carbon and nitrogen, and also by improvement of soil physicochemical properties [52-53]. On the other hand, research conducted by Yang et al. [54] showed that Jerusalem artichoke roots reduce the negative effects of salinization, increasing diversity and the number of microorganisms, and thereby increasing soil enzymatic activity. The cited authors explain the increase in enzymatic activity of the soil on which Jerusalem artichoke was grown by the presence of inulin from tubers of these plants [54]. Inulin, together with pectins and cellulose, binds a large number of unnecessary and harmful compounds such as heavy metals, which can be used in phytoremediation processes [46]. Research conducted by Sas-Nowosielska et al. [48] confirms the beneficial effect of Jerusalem artichoke on the increase in diversity of microorganisms in soil.

The high yield potential, great ability to adapt to soil conditions, and high phytoextraction potential (especially in the case of Albik), speak in favor of using Jerusalem artichoke for phytoremediation of chemically polluted soils $[14,49,55]$.

\section{Conclusions}

1. The highest Jerusalem artichoke yield was obtained in the treatment where 10 and $20 \mathrm{Mg}$ DM sewage sludge per hectare had been applied. Albik had a higher yield than Rubik.

2. Increasing doses of sewage sludge had a considerable effect on the increase in heavy metal content in the tested Jerusalem artichoke varieties. At the highest dose of sewage sludge, Albik had a higher content of $\mathrm{Zn}, \mathrm{Cd}$, and $\mathrm{Pb}$ than Rubik, whereas Rubik had a higher content of $\mathrm{Cu}$ and Ni than Albik.

3. Compared to Rubik, Albik extracted more heavy metals from the sewage sludge.
4. When assessing the Jerusalem artichoke's phytoextraction potential, it was established that Albik phytoremediated metals to a higher degree than Rubik.

5. From the point of view of efficiency of phytoextraction of heavy metals from municipal sewage sludge, Albik (due to higher yield, content, and uptake of heavy metals) can be recommended for phytoremediation of this waste.

\section{Acknowledgements}

Our research was financed by the Ministry of Science and Higher Education of the Republic of Poland (grant No. NN310080336).

\section{References}

1. KIM R.Y., YOON J.K., KIM T.S., YANG J.E., OWENS G., KIM K.R. Bioavailability of heavy metals in soils: definitions and practical implementation - a critical review. Environmental Geochemistry Health, 37, 1041, 2015.

2. MAESTRI E., MARMIROLI M., VISIOLI G., MARMIROLI N. Metal tolerance and hyperaccumulation: Costs and trade-offs between traits and environment. Environmental and Experimental Botany, 68, 1, 2010.

3. CUI S., ZHOU Q., CHAO L. Potential hyperaccumulation of $\mathrm{Pb}, \mathrm{Zn}, \mathrm{Cu}$ and $\mathrm{Cd}$ in endurant plants distributed in an old smeltery, northeast China. Environmental Geology, 51 (6), 1043, 2007.

4. DICKINSON N.M., BAKER A.J.M., DORONILA A., LAIDLAW S., REEVES R.D. Phytoremediation of inorganics: realism and synergies. International Journal of Phytoremediation, 11 (2), 97, 2009.

5. ANTONKIEWICZ J., KOŁODZIEJ B., BIELIŃSKA E. The use of reed canary grass and giant miscanthus in the phytoremediation of municipal sewage sludge. Environmental Science and Pollution Research, 23 (10), 9505, 2016.

6. SHI G., CAI Q. Cadmium tolerance and accumulation in eight potential energy crops. Biotechnology Advances, 27 (5), 555, 2009.

7. ZHANG X., XIA H., LI Z., ZHUANG P., GAO B. Potential of four forage grasses in remediation of $\mathrm{Cd}$ and $\mathrm{Zn}$ contaminated soils. Bioresoource Technology, 101, 2063, 2010.

8. TERZIĆ S., ATLAGIĆ J., MAKSIMOVIĆ I., ZEREMSKI T., ZORIĆ M., MIKLIČ V., BALALIĆ I. Genetic variability for concentrations of essential elements in tubers and leaves of Jerusalem artichoke (Helianthus tuberosus L.). Scienta Horticulturae, 136, 135, 2012.

9. YANG L., HE Q.S., CORSCADDEN K., UDENIGWE C.C. The prospects of Jerusalem artichoke in functional food ingredients and bioenergy production. Biotechnology Reports, 5, 77, 2015.

10. BALDINI M., DANUSO F., TURI M., VANNOZZI G.P. Evaluation of new clones of Jerusalem artichoke (Helianthus tuberosus L.) for inulin and sugar yield from stalks and tubers. Industrial Crops and Products, 19 (1), 25, 2004.

11. PAKARINEN A., MAIJALA P., STODDARD F.L., SANTANEN A., TUOMAINEN P., KYMÄLÄINEN M., 
VIIKARI L. Evaluation of annual bioenergy crops in the boreal zone for biogas and ethanol production. Biomass and Bioenergy, 35, 7, 3071, 2011.

12. KIM S., KIM C.H. Evaluation of whole Jerusalem artichoke (Helianthus tuberosus L.) for consolidated bioprocessing ethanol production. Renewable Energy, 65, 83, 2014.

13. MA X.M., HANG L.H., SHAO H.B., XU G., HANG F., NI F.T., BRESTIC M. Jerusalem artichoke (Helianthus tuberosus), a medicinal salt-resistant plant has high adaptability and multiple-use values. Journal of Medicinal Plants Research, 5, 8, 1272, 2011.

14. WILLSCHER S., JABLONSKI L., FONA Z., RAHMI R., WITTIG J. Phytoremediation experiments with Helianthus tuberosus under different $\mathrm{pH}$ and heavy metal soil concentrations. Hydrometallurgy, 168, 153, 2017.

15. JASIEWICZ C., ANTONKIEWICZ J. Heavy metals extraction by Jerusalem artichoke (Helianthus tuberosus $L$.) from soils contaminated with heavy metals. Ecological Chemistry and Engineering, 9 (4), 379, 2002.

16. REGULATION. Regulation of the Minister of the Natural Environment on municipal sewage sludge dated 6 February 2015. (Rozporządzenie Ministra Środowiska z dnia 6 lutego 2015 r. w sprawie komunalnych osadów ściekowych. Dz. U. RP, Poz. 257). Journal of Laws of Poland, Item 257, 2015 [In Polish].

17. SMITH S.R. A critical review of the bioavailability and impacts of heavy metals in municipal solid waste composts compared to sewage sludge. Environment International, 35, $142,2009$.

18. KELESSIDIS A., STASINAKIS A.S. Comparative study of the methods used for treatment and final disposal of sewage sludge in European countries. Waste Management, 32 (6), 1186, 2012

19. TELLA M., DOELSCH E., LETOURMY P., CHATAING S., CUOQ F., BRAVIN M.N., SAINT MACARY H. Investigation of potentially toxic heavy metals in different organic wastes used to fertilize market garden crops. Waste Management, 33 (1), 184, 2013.

20. BORKOWSKA H., JACKOWSKA I., PIOTROWSKI J., STYK B. Suitability of cultivation of some perennial plant species on sewage sludge. Polish Journal of Environmental Studies, 10 (5), 379, 2001.

21. CHEN L., LONG X.H., ZHANG Z.H. ZHENG X.T., RENGEL Z., LIU Z.P. Cadmium accumulation and translocation in two Jerusalem artichoke (Helianthus tuberosus L.) cultivars. Pedosphere, 21 (5), 573, 2011.

22. KORZENIOWSKA J., STANISŁAWSKA-GLUBIAK E. Phytoremediation potential of Miscanthus $\mathrm{x}$ giganteus and Spartina pectinata in soil contaminated with heavy metals. Environmental Science and Pollution Research, 22 (15), 11648, 2015.

23. LAIDLAW S.W., BAKER A.J.M., GREGORY D., ARNDT S.K. Irrigation water quality in fluences heavy metal uptake by willows in biosolids. Journal of Environmental Management, 155, 31, 2015.

24. POLISH SOIL CLASSIFICATION. (Systematyka gleb Polski). Soil Science Annual, 62 (3), 1, 2011 [in Polish].

25. SOIL SURVEY STAFF. Keys to Soil Taxonomy, 12th ed. USDA-Natural Resources Conservation Service, Washington, D.C., 360, 2014.

26. WRB. 2015. World Reference Base for Soil Resources 2014, update 2015. International soil classification system for naming soils and creating legends for soil maps. World Soil Resources Reports No. 106. FAO, Rome.

27. REGULATION. Regulation of the Minister of the Natural Environment on soil quality and earth quality dated $9 \mathrm{Sep}-$ tember 2002. (Rozporządzenie Ministra Środowiska z dnia 9 września 2002 r. w sprawie standardów jakości gleby oraz standardów jakości ziemi. Dz. U. RP, Nr 165, poz. 1359). Journal of Laws of Poland, No 165, Item 1359, 2002 [In Polish].

28. WASTE CATAlOGUE. 2014. Regulation of the Minister of the Natural Environment on catalog of wastes dated 9 December 2014. (Rozporządzenie Ministra Środowiska z dnia 9 grudnia 2014 r. w sprawie katalogu odpadów. Dz. U. RP, Poz. 1923). Journal of Laws of Poland, Item 1923, 2014 [In Polish].

29. KOŁODZIEJ B., ANTONKIEWICZ J., SUGIER D. Miscanthus $\times$ giganteus as a biomass feedstock grown on municipal sewage sludge. Industrial Crops and Products, 81, 72-82, 2016.

30. OSTROWSKA A., GAWLIŃSKI S., SZCZUBIAŁKA Z. 1991. Methods of analysis and assessment of soil and plant properties. A Catalgoue. (Metody analizy i oceny właściwości gleb i roślin. Katalog). Publisher: Institute of Environmental Protection - National Research Institute, Warsaw, 334, 1991 [in Polish].

31. KUSZNIEREWICZ B., BĄCZEK-KWINTA R., BARTOSZEK A., PIEKARSKA A., HUK A., MANIKOWSKA A., ANTONKIEWICZ J., NAMIEŚNIK J., KONIECZKA P. The dose-dependent influence of zinc and cadmium contamination of soil on their uptake and glucosinolate content in white cabbage (Brassica Oleracea var. Capitata F. Alba). Environmental Toxicology and Chemistry, 31 (11), 2482, 2012.

32. JONES J.B.JR., CASE V.V. Sampling, Handling, and Analyzing Plant Tissue Samples. In RL Westerman, ed, Soil Testing and Plant Analysis, Ed 2. SSSA Book Series, No. 3. Soil Science Society of America, Madison, WI, 389, 1990.

33. THALMANN A. Zur methodik der bestimmung der Dehydrogenaseaktivit $\sim t t$ im Boden mittels Triphenyltetrazoliumchlorid (TTC). Landwirtsch Forsch, 21, 249, 1968.

34. TABATABAI M.A., BREMNER J.M. Use of p-nitrophenyl phosphate for assay of soil phosphatase activity. Soil Biology and Biochemistry, 1 (4), 301, 1969.

35. ZANTUA M.I., BREMNER J.M. Comparison of methods of assaying urease activity in soils. Soil Biology and Biochemistry, 7 (4-5), 291, 1975.

36. LADD J.N., BUTLER J.H.A. Short-term assays of soil proteolytic enzyme activities using proteins and dipeptide derivatives as substrates. Soil Biology and Biochemistry, 4 (1), 19, 1972.

37. ZHANG Z.G., YAO D.X., ZHENG Y.H., GAO L.M. The phytoremediation potential of six compositae plants to soil pollution of heavy metal in coal mine collapse and reclaimed area. Journal of China Coal Society, 10. (B) Chemistry/ Metallurgy/ Environment/ Mine Industry, http://en.cnki. com.cn/Article_en/CJFDTOTAL-MTXB201010033.htm 2010.

38. JOHNSON G.A., WYSE D., SHEAFFER C.C. Yield of perennial herbaceous and woody biomass crops over time across three locations. Biomass and Bioenergy, 58, 267, 2013.

39. ALVARENGA P., MOURINHA C., FARTO M., SANTOS T., PALMA P., SENGO J., MORAIS M.C., CUNHAQUEDA C. Sewage sludge, compost and other representative organic wastes as agricultural soil amendments: Benefits versus limiting factors. Waste Management, 40, 44, 2015.

40. JOHANSSON E., PRADE T., ANGELIDAKI I., SVENSSON S.E., NEWSON W.R., GUNNARSSON I.B., HOVMALM H.P. Economically viable components 
from Jerusalem Artichoke (Helianthus tuberosus L.) in a biorefinery concept. International Journal of Molecular Science, 16, 8997, 2015.

41. LONG X.H., SHAO H.B., LIU L., LIU L.P., LIU Z.P. Jerusalem artichoke: A sustainable biomass feedstock for biorefinery. Renewable and Sustainable Energy Reviews, 54, 1382, 2016.

42. KAYS S.J., NOTTINGHAM S.F. Biology and chemistry of Jerusalem artichoke Helianthus tuberosus L. CRC Press, Taylor and Francis Group, Boca Raton - Abingdon - Oxon New York 2008. 478, 2008.

43. LI L., SHAO T., YANG H., CHEN M., GAO X., LONG X., SHAO H., LIU Z., RENGEL Z. The endogenous plant hormones and ratios regulate sugar and dry matter accumulation in Jerusalem artichoke in salt-soil. Science of the Total Environment, 578, 40, 2017.

44. BACH V., KIDMOSE U., BJØRN G.K., EDELENBOS M. Effects of harvest time and variety on sensory quality and chemical composition of Jerusalem artichoke (Helianthus tuberosus) tubers. Food Chemistry, 133 (1), 82, 2012.

45. LONG X., NI NI., LIU Z., RENGEL Z., JIANG X., SHAO $\mathrm{H}$. Tissue fractions of cadmium in two hyperaccumulating Jerusalem artichoke genotypes. The Scientific World Journal, Article ID 421249: 6, 2014.

46. SAWICKA B., NOAEMA A.H., HAMEED T.S., SKIBA D. Genotype and environmental variability of chemical elements in potato tubers. Acta Sci. Pol. Agricultura, 15 (3), 79, 2016.

47. GIZIŃSKA-GÓRNA M., CZEKAŁA W., JÓŹWIAKOWSKI K., LEWICKI A., DACH J., MARZEC M., PYTKA A., JANCZAK D., KOWALCZYK-JUŚKO A. The possibility of using plants from hybrid constructed wetland wastewater treatment plant for energy purposes. Ecological Engineering, 95, 534, 2016.

48. SAS-NOWOSIELSKA A., GALIMSKA-STYPA R., KUCHARSKI R., ZIELONKA U., MAŁKOWSKI U.,
GRAY L. Remediation aspect of microbial changes of plant rhizosphere in mercury contaminated soil. Environmental Monitoring Assessment, 137 (1), 101, 2008.

49. LONG X., NI NI., WANG L., WANG X., WANG J., ZHANG Z., ZED R., LIU Z., SHAO H. Phytoremediation of Cadmium-Contaminated Soil by Two Jerusalem Artichoke (Helianthus tuberosus L.) Genotypes. Clean - Soil, Air, Water, 41 (2), 202, 2013.

50. CIARKOWSKA K., GARGIULO L., MELE G. Natural restoration of soils on mine heaps with similar technogenic parent material: A case study of long-term soil evolution in Silesian-Krakow Upland Poland. Geoderma, 261, 141, 2016.

51. MEDINA J., MONREAL C., BAREA J.M., ARRIAGADA C., BORIE F., CORNEJO P. Crop residue stabilization and application to agricultural and degraded soils: A review. Waste Management, 42, 41, 2015.

52. WISZNIEWSKA A., HANUS-FAJERSKA E., MUSZYŃSKA E., CIARKOWSKA K. Natural organic amendments for improved phytoremediation of polluted soils: A review of recent progress. Pedosphere, 26 (1), 1, 2016.

53. ONTL T.A., CAMBARDELLA C.A., SCHULTE L.A., KOLKA R.K. Factors influencing soil aggregation and particulate organic matter responses to bioenergy crops across a topographic gradient. Geoderma, 255-256, 1, 2015.

54. YANG H., HU J., LONG X., LIU Z., RENGEL Z. Salinity altered root distribution and increased diversity of bacterial communities in the rhizosphere soil of Jerusalem artichoke. Scientific Reports, 6, 20687, 10, 2016.

55. SAWICKA B., KALEMBASA D. Annual variability of some toxic element contents $(\mathrm{Cd}, \mathrm{Cr}, \mathrm{Co}, \mathrm{Ni}$, and $\mathrm{Pb})$ and response of two Jerusalem Artichoke varieties to increasing nitrogen fertilizer at constant PK levels. Polish Journal of Environmental Studies, 22, 3, 861, 2013. 